\title{
TIMELESS WIND
}

The wind has blown for eternity, Never looking back, never giving in. Never staying long, always running on, Always running endlessly. (1)

\section{By Emily Kuecker, Representing the South Dakota Section of SRM.}

Editor's Note: This article was the second place paper presentation in the annual High School Youth Forum competition at the 2004 SRM Meetings in Salt Lake City, Utah.

\section{Society for Range Manageinent}

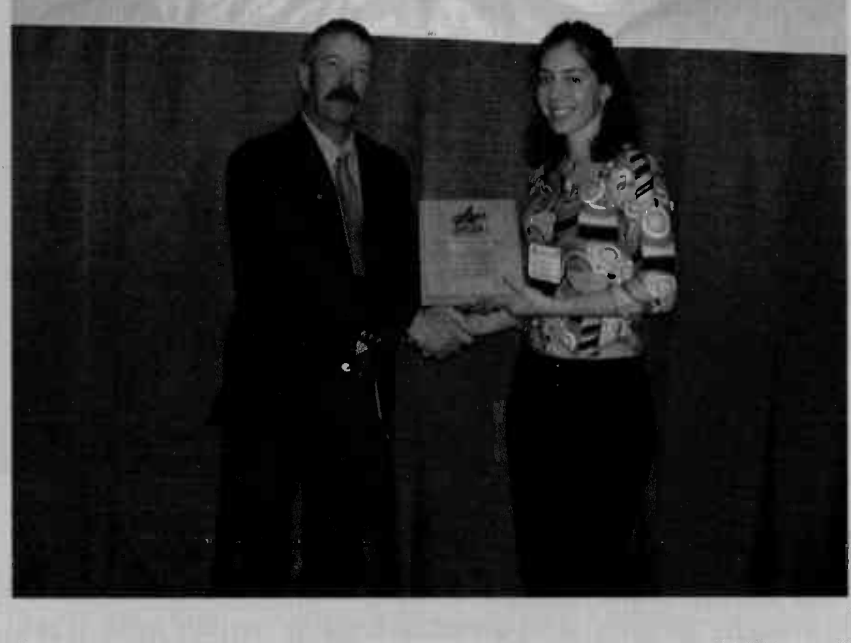

$\mathrm{T}$ hrough decades wind has been our foe, and it's been our friend. I am going to explore three points of relationships pertaining to the struggles, enhancement, and productive use of our world's natural resource, Timeless Wind.

\section{The Dust Bowl Days}

My first point looks back in history discovering the struggles during a time of hardship. If I had lived in the days of the Dirty 30's and farmed the drought land of the America's Midwest, I would have been overwhelmed by the conditions caused by the wild wind. At first there was not much to worry about, but as time went by with no rain, the situation became worse day by day. The only trees were located along creeks and streams. That meant the wind had great opportunities to sweep across the land moving the soil along with it.

Farmers burned residue off the fields for easier seeding. They used plows to work the fields into fine dry soil to plant their crops. The soil acted as sandpaper and the action of the wind kept all vegetation from growing. The wind had a "field day" on the tilled land. Up and down and away the topsoil went. Eventually the wind finally stopped for a time. There was a red layer of dust covering everything, blown in from another region. Other times the covering was a gray dust from when the wind switched directions.

Dust was everywhere. The people ate it and slept with it. Rags were stuffed into every crack (9). Dirt drifted against buildings and fence lines. It was a sad, sad time, but it brought a positive change. The Dust Bowl Days taught farmers and ranchers new methods and techniques to minimize the adverse effects of the wind (9).

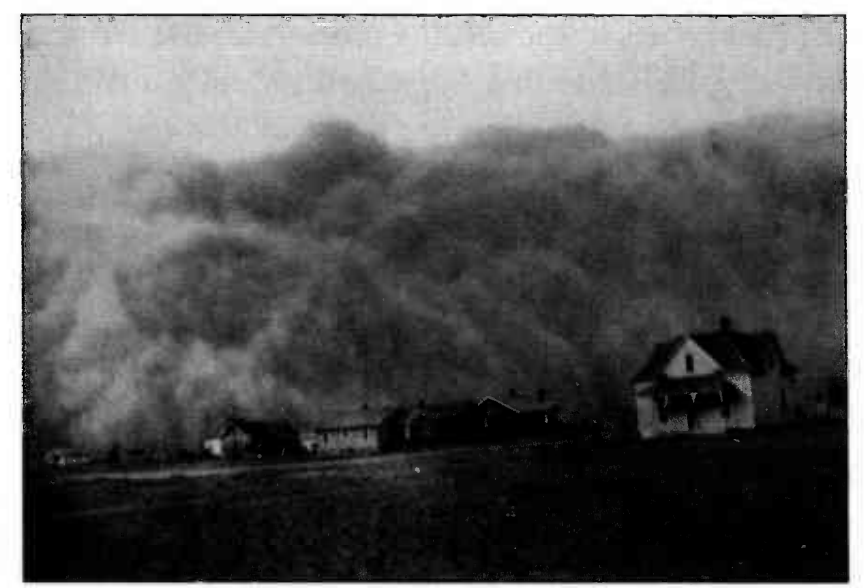

The Dirty Thirties: Dustbowl dirt storm. 


\section{Learning To Better Manage The Land}

This brings me to my second point, enhancement. By this, I refer to how we have improved and reclaimed our prairies and fields. Wind erosion has plagued agriculture for many decades. Today we have found a neutral standing with the wind. We have been able to work with our relationship by developing new technologies and farming practices.

The best way to prevent wind erosion and conserve soil moisture is to maintain the land with either a good crop residue or with a vegetative cover. Leaving crop residue reduces the wind speed at the soil surface (10). Also, the standing stubble and plant life anchors the soil, helps reduce evaporation, and traps snow. A program designed to maintain vegetative cover is the Conservation Reserve Program, also known as CRP (10). The CRP protects the soil from wind erosion, increases the organic matter, and promotes wildlife habitat.

Next, planting and maintaining field shelterbelts provides extra protection against wind erosion by reducing the wind's velocity. A successful shelterbelt usually consists of a combination of trees and shrubs (5). Planting at least three rows helps to achieve a good wind protection (5). A hardy Black Hills spruce seedling is a suitable choice to plant in my area. It would be the foundation of my shelterbelt.

Last, avoid overgrazing and leave adequate plant cover to prevent the exposure of soil. Monitor the grass closely and after half of the forage is grazed, move the livestock onto a new area (4). Pasture

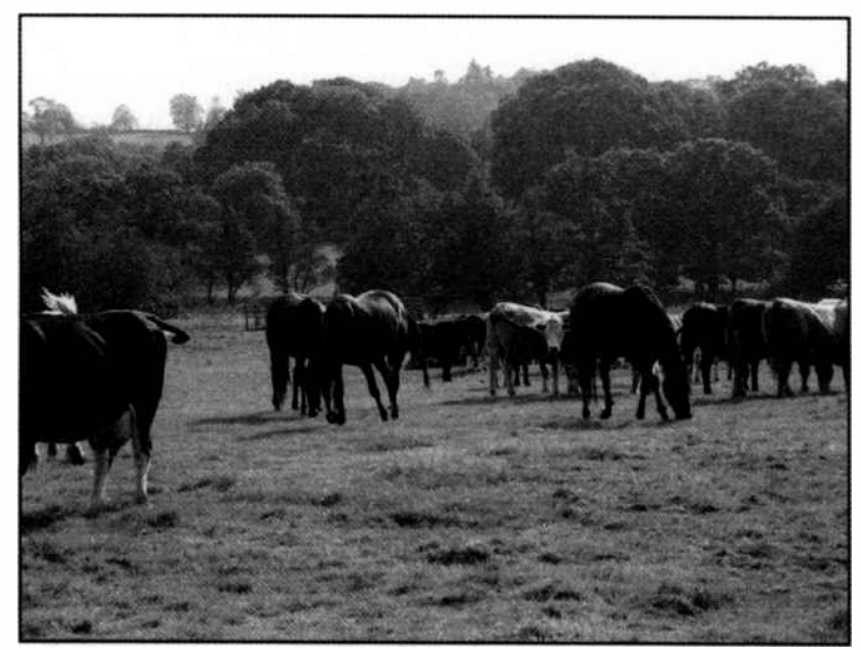

Avoiding overgrazing.

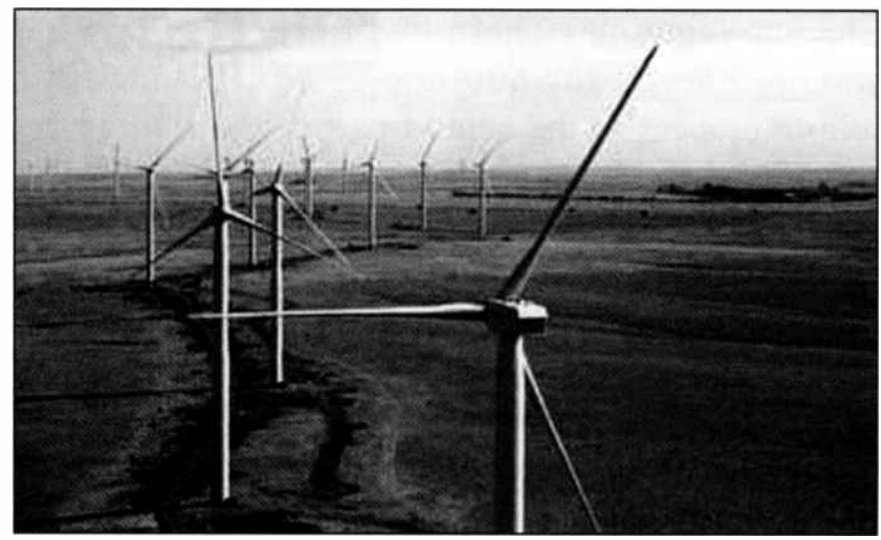

Highmore, South Dakota

conditions have grown healthier over the years through rotational grazing.

We have learned valuable lessons from the happenings of the 30's. With today's farming equipment and grazing management practices, wind erosion control can easily be a part of field and pasture management systems. Someone once told me that being a good steward of the land is taking responsibility for the land on which we live.

\section{Utilizing The Wind}

My final point refers to the productive use of wind. The wind has taken advantage of us long enough. Now it is our turn to take advantage of the wind. We are now harnessing the wind as an energy source. No other power generation technology can match wind's energy growth rate (8). Wind energy is growing $25 \%$ faster than oil or coal annually (8).

Sleek wind turbines are beginning to elegantly grace South Dakota prairie landscapes. The wind turbine works the opposite of a fan. Instead of using electricity to make wind like a fan, wind turbines use the wind to make electricity. An upwind turbine has three blades that face into the wind. The actual size of each blade stretches out 100 feet (5). This mighty structure stands 200 feet high (5). The wind turns the blades, then spins a shaft, which connects to a generator and makes electricity.

Mention South Dakota's weather to most residents and they'll think of one word, "wind" (7). South Dakota's gusty winds have earned a national fourth place wind energy potential ranking( 3 ). Two wind towers have been proudly erected in the 
Chamberlain area. These two towers can provide enough energy for 600 homes (3)! Highmore's rolling prairies in the central part of the state is the site of 27 new turbines (6). The wind farm will not only produce $40 \mathrm{MW}$ of power, but also generates new income for the landowner (6). It is a win, win situation. Wind energy has the potential to be America's fuel and become a source of American strength and independence from other countries (2).

Wind energy is a free, clean, renewable resource, so no matter how much is used today, there will always be the same supply in the future.

In conclusion: Timeless Wind is our fierce friend. The mighty force of wind has gone from causing hardships, to enhancement, to a powerful productive source of advancement and efficiency.

Conservation means harmony between man and his resources. When the land does well for its owner and then the owner does well by his land and both end up better because of their partnership, we will have a better tomorrow.

The wind has blown for eternity, Never looking back, never giving in. Never staying long, always running on, Always running endlessly. (1)

Emily Kuecker is a high school student at Webster, South Dakota.

\section{Bibliography}

Interview (10) Kuecker, Richard, personal communications, March 25, 2003

Newspapers (6) Aberdeen American News, 1 A, March 28, 2003

Pamphlets

(8) Harvesting the Wind, April 2002

(2) Prairie Winds, Vo.I, No.5: 1-4, November 2001

Song

(1) Chinitor, Vanessa, "Like the Wind", www.LetsSingIt.com, March 1999

Web sites

(3) American Wind Energy Association, http://www.awea.org/, February 2002

(9) Bonnifield, Paul, The Dust Bowl, Men, Dirt, and Depression.

http://www.ptsi.net/user/museum/dustbowl.html, December 9, 2003

(5) Government of Alberta,

http://wwwl lagric.gov.ab.ca/\$department/deptdocs.nsf/all/agd ex2073 May 4, 2001

(4) Rayburn, Ed, Overgrazing Can Hurt Environment, Your Pocketbook.

http://www.wvu.edu, October 25, 2002

(7) South Dakota Hopes To Harness Wind as Energy Resource, www.greennature.com, May 2002 